\title{
The Teaching Reform of Structure Design Principle based on the CDIO
}

\author{
Bo YAN, Fei LIU, Zhigang JIANG \\ College of Basic Education, National University of Defense Technology, Changsha, Hunan 410073, PR \\ China \\ Yuhui ZHOU \\ College of Science, Central South University of Forestry Technology, Changsha, Hunan 410073, PR China
}

\begin{abstract}
A teaching reform of structure design principle to cultivate and improve undergraduate' innovative ability based on the CDIO engineering education mode and the research teaching conception is discussed in this paper. The course teaching objects and syllabus are investigated, and the course teaching contents and the corresponding teaching methods, as well as the process of course teaching, are designed. Practices show that the teaching reform can build an integrated learning environment based the CDIO, and cultivate undergraduate' innovative ability, improve undergraduate' practice ability and comprehensive quality. KEYWORD: Teaching reform; CDIO mode; Research teaching; Undergraduate' innovative practice
\end{abstract}

\section{INTRODUCTION}

The CDIO (abbreviation of Conceiving, Designing, Implementing and Operating) engineering education mode is one of the latest achievements of the $21 \mathrm{st}$ century international engineering education reform [1]. The CDIO mode establishes an integrative and reasonable course system to make undergraduate learn actively and learn in practice 错误! 未找到 引用源。.The CDIO mode emphasizes not only on undergraduate' basic knowledge learning, but also on cultivating the undergraduate' comprehensive quality (professional ethics, social responsibility, innovation, co-operation, etc.). Integration is the key point of the CDIO model [3], which means that undergraduate can obtain an integrative experience and approach after the integrative course system learning. The CDIO teaching syllabus and goals provide comprehensive and operational implementation guidance to train engineering talents. Sine the CDIO mode was introduced in domestic in 2005, Tsinghua University, Beijing Jiaotong University, Shantou University, and etc. had carried on the positive exploration, research and practice, and their results provided feasible examples of engineering education reforms, course system construction, and course teaching reforms in our country [4-8]. Researches and practices show that the CDIO mode is conducive to the cultivation of the undergraduate' engineering innovation and practical ability.

To promote education reforms and cultivate excellent innovative talents, the Ministry of
Education initiated National Undergraduate Training Programs for Innovation and Entrepreneurship, which included three categories (Innovation training project, entrepreneurship training project and entrepreneurial practice project). At the same time, the Ministry of Education demanded that the National Undergraduate Training Programs for Innovation and Entrepreneurship should be introduced into the education scheme. What's more, some provinces and universities provided corresponding innovation training projects also. All of the innovation projects require undergraduate to complete the conceiving, design, research and implement of the projects under the guidance of teachers, and the application of project results, etc. Thereafter, the innovation projects provide an open platform for undergraduate to obtain an integrative experience and approach through learning and practicing active.

It is an urgent issue to combine the innovation projects with the course teaching reasonably [9]. In recent years, the author of this paper had carried on the teaching reforms of structures design principle to cultivate undergraduates' innovation recurring to the innovation projects platform based on the CDIO engineering education mode and research teaching conception, and got some promising results. In this paper, the course teaching objects and syllabus of structure design principle are investigated, and the course teaching contents and the corresponding teaching methods, as well as the process of course teaching, are designed. 


\section{TEACHING GOALS AND SYLLABUS}

The course system of engineering structure design theory is an important professional basic course of civil engineering, which has an irreplaceable action on discovering relationships among engineering, social economy and the humanities activities [10, 11]. Structure design principle is a professional basic compulsory course of Highway and Bridge Engineering in our university. The main contents the course includes structure design theory and methods, structure materials basic properties, steel structure and reinforced concrete structure basic design and calculation principle, and etc. The structure design principle teaching reform based on the CDIO mode realized the connection of the course teaching and innovation projects, created an integrative environment of learning, exploration, innovation, practice and experience, and paid attention to the undergraduates' engineering foundation knowledge learning and comprehensive ability cultivation.

Table 1 structure design principle syllabus based on the CDIO

\begin{tabular}{|c|c|c|c|c|c|}
\hline \multicolumn{2}{|c|}{ CDIO syllabus } & \multicolumn{4}{|c|}{ structure design principle syllabus } \\
\hline \multirow{2}{*}{ high-level } & \multirow{2}{*}{ the second level } & \multirow{2}{*}{ the second level } & \multicolumn{3}{|c|}{ teaching goal* } \\
\hline & & & memory & understand & application \\
\hline \multirow{5}{*}{$\begin{array}{l}\text { 1. technical knowledge } \\
\text { and reasoning }\end{array}$} & $\begin{array}{l}\text { 1.1 knowledge of science } \\
\text { underlying }\end{array}$ & $\begin{array}{c}1.1 \text { structural design theory and } \\
\text { structural reliability theory }\end{array}$ & $\mathrm{C}$ & $\mathrm{C}$ & $\mathrm{C}$ \\
\hline & \multirow[b]{2}{*}{$\begin{array}{l}1.2 \text { core engineering } \\
\text { fundamental knowledge }\end{array}$} & \begin{tabular}{|l}
$\begin{array}{l}\text { 1.2.1 probability limit state and } \\
\text { structural material properties }\end{array}$ \\
\end{tabular} & B & B & $\mathrm{B}$ \\
\hline & & $\begin{array}{l}\text { 1.2.2 mechanical properties and } \\
\text { designing of basic structural } \\
\text { components }\end{array}$ & $\mathrm{B}$ & $\mathrm{B}$ & A \\
\hline & \multirow{2}{*}{$\begin{array}{l}1.3 \text { advanced engineering } \\
\text { fundamental knowledge }\end{array}$} & $\begin{array}{l}\text { 1.3.1 new material and structure } \\
\text { theme }\end{array}$ & & $\mathrm{C}$ & $\mathrm{C}$ \\
\hline & & 1.3.2 Innovation projects & & & $\mathrm{A}$ \\
\hline \multirow{5}{*}{$\begin{array}{l}\text { 2. Personal and } \\
\text { professional skills and } \\
\text { attributes }\end{array}$} & $\begin{array}{c}2.1 \text { engineering reasoning } \\
\text { and problem solving }\end{array}$ & \begin{tabular}{|l|}
$\begin{array}{l}2.1 \text { engineering reasoning and } \\
\text { problem solving }\end{array}$ \\
\end{tabular} & & $\mathrm{B}$ & $\mathrm{B}$ \\
\hline & $\begin{array}{r}2.2 \text { experimentation and } \\
\text { knowledge discovery }\end{array}$ & $\begin{array}{l}2.2 \text { experimentation and } \\
\text { knowledge discovery }\end{array}$ & A & $\mathrm{B}$ & A \\
\hline & 2.3 system thinking & 2.3 system thinking & $\mathrm{B}$ & $\mathrm{B}$ & $\mathrm{C}$ \\
\hline & $\begin{array}{l}2.4 \text { personal skills and } \\
\text { attitudes } \\
\end{array}$ & 2.4 personal skills and attitudes & $\mathrm{C}$ & $\mathrm{B}$ & $\mathrm{B}$ \\
\hline & \begin{tabular}{|c|}
2.5 professional skills and \\
attitudes
\end{tabular} & 2.5 professional skills and attitudes & & $\mathrm{B}$ & $\mathrm{B}$ \\
\hline \multirow{3}{*}{$\begin{array}{l}\text { 3. Interpersonal skills: } \\
\text { teamwork and } \\
\text { communication }\end{array}$} & \begin{tabular}{|l}
3.1 multi-disciplinary \\
teamwork
\end{tabular} & 3.1 multi-disciplinary teamwork & & A & B \\
\hline & 3.2 communications & 3.2 communications & & A & $\mathrm{B}$ \\
\hline & $\begin{array}{c}3.3 \text { communications in } \\
\text { foreign languages }\end{array}$ & \begin{tabular}{|l|}
3.3 communications in foreign \\
languages
\end{tabular} & & $\mathrm{C}$ & \\
\hline \multirow{6}{*}{$\begin{array}{l}\text { 4. Conceiving, designing, } \\
\text { implementing, and } \\
\text { operating systems in } \\
\text { the enterprise and } \\
\text { societal context }\end{array}$} & $\begin{array}{l}4.1 \text { external and societal } \\
\text { context }\end{array}$ & 4.1 external and societal context & $\mathrm{D}$ & & \\
\hline & \begin{tabular}{|l}
4.2 enterprise and business \\
context
\end{tabular} & 4.2 enterprise and business context & $\mathrm{D}$ & & \\
\hline & $\begin{array}{r}4.3 \text { conceiving and } \\
\text { engineering systems } \\
\end{array}$ & \begin{tabular}{|l|}
4.3 conceiving and engineering \\
systems
\end{tabular} & & B & A \\
\hline & 4.4 designing & 4.4 designing & & $\mathrm{B}$ & A \\
\hline & 4.5 implementing & 4.5 implementing & & $\mathrm{C}$ & $\mathrm{C}$ \\
\hline & 4.6 operating & 4.6 operating & & $\mathrm{D}$ & $\mathrm{D}$ \\
\hline
\end{tabular}

* A, B, C, D and blank in the target column indicate ability requirements, A means the highest requirements, and blank means no requirement.

The CDIO syllabus provides a complete framework for setting down research course syllabus. As shown in Table 1, the CDIO Syllabus classifies learning outcomes into four high-level categories, containing 17 details at the second level [1]. The syllabus and teaching objects of structure design principle based on the CDIO syllabus are listed also in table 1. After the course learning, undergraduate should not only have the basic ability of design and calculation of basic structural and components independently, but also put forward an innovation project after the study of new structure. 


\section{COURSE DESIGN}

\subsection{Teaching design}

The teaching of structure design principle makes full use of the network course platform to combine teaching in classroom and learning out of classroom closely. The main teaching sections, the main teaching contents and teaching manners corresponding are shown in Table 2 . There are three sections, i.e. the learning of the basic theory and principle, the introduction of themes and the team innovation projects based on the CDIO. The main contents of the first section include the development of the theory of structure design, structure reliability conception, structure material properties, probabilistic limit state design method and the design and calculation principle of structure components, which are the foundation of the course and are implemented in the classroom. The main contents of the second section are about new materials and new structures, containing the research background and significance, analysis of cases, and introduction of structure innovation approaches, which are implemented in the classroom also. The main contents of the third section consist of five parts, the first part is individual theme choice interested and getting an innovative idea, then teachers divide undergraduate with almost the same idea into one team; the second part is team theme choice and obtaining team idea after communications in classroom; the third part is team preliminary design based on the team idea after school; the fourth part is the report of the team preliminary design in classroom, then is teachers' evaluation on the design and advices for improvement; the last part is the preliminary designing modification and the innovation projects application.

Table 2 Teaching processes and teaching contents

\begin{tabular}{|c|c|c|}
\hline teaching section & teaching content & teaching manner \\
\hline 1. the basic theory and principle & $\begin{array}{l}\text { the theory of structure design, structural reliability conception, } \\
\text { structural material properties, probabilistic limit state design } \\
\text { method, the design principle of structural components. }\end{array}$ & in classroom \\
\hline $\begin{array}{l}\text { 2. the introduction of new material } \\
\text { and new structure themes }\end{array}$ & $\begin{array}{l}\text { the research background and significance, analysis of cases, } \\
\text { structure innovation approaches. }\end{array}$ & in classroom \\
\hline \multirow{5}{*}{$\begin{array}{l}\text { 3. the team innovation projects } \\
\text { based on the CDIO }\end{array}$} & $\begin{array}{l}\text { individual theme choice interested, getting an innovative idea, } \\
\text { forming innovation project teams. }\end{array}$ & out of classroom \\
\hline & team theme choice, communications, obtaining team idea. & in classroom \\
\hline & team preliminary design, team discussions & out of classroom \\
\hline & team preliminary designing report, teacher evaluations & in classroom \\
\hline & $\begin{array}{l}\text { the preliminary designing modification and the innovation projects } \\
\text { application. }\end{array}$ & out of classroom \\
\hline
\end{tabular}

The process from conceiving to implementing is an important character of the CDIO, which can inspire undergraduate learning enthusiasms, can improve undergraduate comprehensive abilities and consolidate the basic knowledge. To have undergraduate get the integrative experiences of structure innovation through the CDIO mode, the course teaching must be extended from the classroom into after-school, and the practice projects should be introduced into teaching. Therefore, at the end of the course teaching, the team should improve the preliminary design in accordance with the requirements of the innovation projects, carry out some testing experiences, write a project application corresponding.

\subsection{Practice projects}

In recent years, the national university of defense technology provides a variety of open platforms, such as the Innovative Plan, the Great Wall Information Cup and the Challenge Cup, for undergraduates to carry out the innovative practice.
The amount of the innovation projects applied successful is more than 200 each year. Undergraduates take part in the whole process of the project application, the scheme design, model making, experimental testing and research report writing, therefore, the comprehensive qualities, such as the innovative ability, the team operation spirit and the communication ability, are improved. All of the platforms can be made good use of during the course teaching to establish the integration of learning environment based on the CDIO.

\subsection{Organization and implementation}

\subsubsection{Teaching processes}

The teaching implementation processes of the structure design principle are as follows:

a) The basic theory and principle teaching. The basic theory and principle of structure design, and the structure component calculation are taught in classroom, at the same time, some demonstration experiments are implemented according to the teaching schedule to make undergraduate understand 
better. Teachers should introduce the project design methods and skills and interpret some design codes, to make undergraduates acquaint with the basic process of structure design and calculation. The time of the basic theory and principle teaching is 4 hours a week, lasting six weeks.

b) The theme introduction. There are three themes in the course, that is, the deployable structure, the assembly truss structure and the structure numerical simulation. The research background and significance of the themes, typical cases, structure innovation approaches, and the innovative project guide are introduced in the classroom. At the same time, teachers should pay attention to the knowledge point's analysis in each theme, to consolidate the basic theory and principle learned further and to lay the foundation for the forthcoming structural projects. The time of the themes introduction is 4 hours, lasting one week.

c) The team innovation projects based on the CDIO. First of all, undergraduate select an interested theme based on consulting documents and communicating with teachers and other undergraduates, then take about three weeks to complete the preliminary design. Secondly, in the following week, research teams(each team containing about six members) come into being with the same topic, then team research idea and preliminary designing plan are determined. Thirdly, members of the team take about two weeks to complete the preliminary design; Fourthly, each team reports the preliminary design, focusing on the feasibility analysis and the use of the course knowledge in the preliminary design, then teachers evaluate the team idea and design, put forward modification suggestions; Finally, after the course, team improved their preliminary design, and teachers recommend some excellent to apply for the innovation projects mentioned above.

\subsubsection{Teaching methods}

Teaching methods based on the CDIO engineering educational mode are adopted in the course teaching. The first is that the course teaching follows the procedure of asking questions, analyzing questions and solving problem; the second is flexible application of the case-based teaching method, the dialogue teaching method and the heuristic teaching method; the third is to encouraged undergraduates to participate in discussion and express their opinions; the fourth is that teachers pay attention to impart the research methods to undergraduates. During the course teaching, teachers follow the principle of continuous improvement, sum up experience constantly and find out the key and difficult point of each knowledge point. The teaching contents are not only the explanations of the design code purely, but also the flexible application of the design code. Teachers pay attention to cultivate undergraduates' comprehensive abilities, the practice abilities and the innovative abilities on the basis of the basic concept and principle of structure design teaching. Discussions, seminars and communications can encourage undergraduate to explore and learn in team operation, and stimulate learning interest and improve the undergraduate' CDIO ability.

The theme teaching follows the procedure of issue, idea, inspiration and design. Teachers pay attention to the analysis of the innovative idea or the innovative points of the typical case. The assembly truss structure topic and the structure numerical simulation topic accepted easily, which contact close with the subsequent professional course and can stimulate undergraduate' interest, thinking and imagination, are teaching key points and difficult points of the special topic section.

\subsubsection{Course assessment methods}

A mixed assessment methods combined examination with comprehensive evaluation is implemented. The course total scores are 100, among which the examination scores is 60 and the evaluation scores is 40. The examination close book emphasize on the basic concept and basic theory and some simple calculation. Comprehensive evaluation is consisted of personal evaluation, team evaluation and teacher evaluation. Personal evaluation is a comprehensive assessment by himself (herself) on his (her) the course learning, accounting for $10 \%$ of the course total scores. Team evaluation is another comprehensive assessment by other team members according to individual contributions to the team, accounting for $10 \%$ of the course total scores. Teacher evaluation is a comprehensive assessment also by teachers according to the preliminary design and attendance, accounting for $20 \%$ of the course total scores. The mixed assessment methods of the course pays attention to examining individual open learning ability, team cooperation and communication ability and the managing ability based on the CDIO concept.

\section{PRACTICE AND SUGGESTIONS}

Since structure design principle teaching reform in 2010, undergraduates' innovative consciousness, innovative ability and comprehensive quality have been improved remarkably, and a great deal of innovation projects have been applied for successfully. Up to now, undergraduates obtained 12 projects of the Innovative Plan (8 at the national level, 2 at the provincial level and 2 at university level), 9 projects of the Great Wall Information Cup and 1 project of the Challenge Cup. At the same time, undergraduates obtained 1 third-grade award of the Great Wall Information Cup and 5 patents, and published four papers. In addition, the innovation 
projects were connected with graduation thesis closely. Practices show that the combination has advantage to improve the quality of the thesis and the innovation projects.

\section{CONCLUSIONS}

A teaching reform of structures design principle based on the CDIO engineering education mode and the research teaching conception is presented in this paper to cultivate and improve undergraduates' innovation abilities and comprehensive qualities. The course syllabus containing 17 second-level objects and requirements are set down. The course teaching is divided into three sections, and the main teaching contents corresponding are designed. The course teaching process, the teaching methods and the course assessment methods are investigated. Teaching practices shows that the teaching reform realized the combination of the platform of the Innovative Plan with the course teaching closely, and that the introductions of the research teaching and the Innovative Plan to build an integrated learning environment based the CDIO, is an effective way to cultivate undergraduate' innovative ability, improve undergraduate' practice ability and comprehensive quality.

\section{REFERENCES}

[1] Crawley, E.F., Malmqvist, J., "Ostlund, S., Brodeur, D.R. 2007. Rethinking Engineering Education : The CDIO Approach, Springer, New York.
[2] Jianzhong, C. 2008. The CDIO engineering education reform strategy and the international cooperation between production and learning. China University Teaching, 5: 16-19.

[3] Wenlong, H. 2014. On reform of CDIO-based engineering inquiry teaching mode. Research in Higher Education of Engineering, 1: 163-168.

[4] Peihua, G., Nengsheng, B., Quanli, K., Xiaohua, L., Guangjing, X., Peng, L., Yan, C. 2012. CDIO in China (part I). Research in Higher Education of Engineering, 3: 24-40.

[5] Peihua, G., Nengsheng, B., Quanli, K., Xiaohua, L., Guangjing, X., Peng, L., Yan, C. 2012. CDIO in China (part II). Research in Higher Education of Engineering, 5: 34-45.

[6] Zhigang, H., Shengbing, R., Bing, W. 2010. Build the integration teaching mode based on CDIO concept. China Higher Education, 22: 44-45.

[7] Chun, Z., Zhimin, Z., Fei, L. 2014. Based on CDIO three fraction of professional practice education system research. Education and Vocation, 6: 156-158.

[8] Jun, y. 2014. Teaching reform and practice of analog electronic technology based on the CDIO mode. Education and Vocation, 8: 129-131.

[9] Zhigang, J., Hao, Z., Fei, L. 2014. Structural conception design and innovation based on the CDIO mode. Heilongjiang Researches on Higher Education, 8: 128131.

[10] Yong, X., Jichao, Z., Keyi, W. 2012. Innovation and practice of engineering structure design principle based on the CDIO. Journal of southeast university (philosophy and social sciences), $\mathrm{S}(2): 253-255$.

[11] Hong, Z. 2011. Construction and implementation of CDIO serial courses for civil engineering specialty. Journal of Architectural Education in Institutions of Higher Learning, 6: 89-94. 